\title{
A Comparison of the Effects of Canadian and U.S. Policy Shocks on Canadian Flow - of-Funds Variables
}

\author{
Jacob Cohen* \\ Steven Husted**
}

By means of an integrated, two-country flow-of - funds matrix for Canada and the United States, the impacts on the endogenous Canadian variables of four Canadian and U.S. shock variables were compared. The selected exogenous variables were rest of the world gross saving, gross saving of the federal government, financial sources of funds of the central bank and the financial sources of funds of commercial banks. The endogenous variables for thirteen Canadian sectors included gross saving, capital expenditures, net increases in financial assets and increases in liabilities. Perhaps out most valuable finding is that it is. not the current account surplus that sparks the Canadian economy but rather capital inflows.

\section{Introduction}

One of the most difficult problems researchers encounter in attempting to understand the international transmission of economic behavior lies in modeling the economic linkages between countries. Elsewhere (see Choen-Husted 1985, 1986) we have argued that a useful framework for studying such issues is an integrated flowof-funds matrix. An attraction of this framework is the system of constraints it imposes on any statistical estimation. Apart from the identities underlying any signlecountry matrix, a two-country matrix offers the additional constraints imposed by the bilateral balance of payments. We illustrated such a framework using data from the United States and Canada. Past work centered on forecasting the flow of the funds for 1985. The forecasting technique combined judgment with auto-regressive techniques.

-Professor of Economics and Finance, University of Pittsburgh, U.S.A.

*Associate Professor of Economics, University of Pittsburgh and Senior Staff Economist, Council of Economic Advisers, U.S.A. 
A point of departure in our estimation approach was to treat statistical discrepancy as another variable to be forecast by these methods.

In the present paper center stage is given the sectoring detail of the accounts. One of the advantages of flow of funds modeling in a single country context is that it allows one to study the sectoral impact of a variety of economic shocks. Because we have integrated two flow of funds accounts, our setup allows us to explore these questions as well as to investigate at the sectoral level possible international implications of changes in domestic variables. As a first step in this direction, certain Canadian and U.S. flow variables are treated as exogenous policy variables and entered alternately both unlagged and lagged in the distributed lag equations for the remaining variables of the integrated matrix. The selected exogenous variables for both countries are rest of the world gross saving, gross saving of the federal government, the financial sources of funds of the central bank-a central bank credit proxy-and the financial sources of funds of chartered (commercial) banks-a bank credit proxy.

The value of the approach lies in its ability to track the flow of funds through the economy in response to domestic and external shocks stated in the same flow dimension. A comparison of flow-flow effects from U.S. and Canadian shocks provides a test of Canadian economic independence.

\section{Some Theorizing}

The flow-of-funds schema is suggested in Table $1 .^{1}$ The domestic shock variables exercise flow - of - funds effects that are expected to be positive. The credit entries for net increase in financial liabilities for the Bank of Canada and the chartered banks are responsible for increases in debit entries for the same financial sector. These become sources of funds for a second sector. Encompassed in these positive effects for nonfinancial sectors are price and quantity effects since the flows are in nominal dollars. Similarly the positive effects may embrace exogenous increases in sector borrowing. Such increases cannot be distinguished from induced changes.

Double counting of the effects of the financial shock variables is inevitable. Since all the endogenous cell variables are related to the shock variables, both an increase in capital expenditures financed by an increase in borrowing and the borrowing increase will be attributed to the financial shock variable. The same double couting of effects

\footnotetext{
'In a fully-specified two-country model the rest-of-the-world sector for each country would be bifurcated into the second country and a "foreign" subsector. For data reasons, the sector has not been split and only a single sector is shown in Table 1 . Nevertheless in view of the symmetrical signs that would be expected from the bilateral balance of payments, one can deduce whether third-country influences are at work on the Canadian flows.
} 


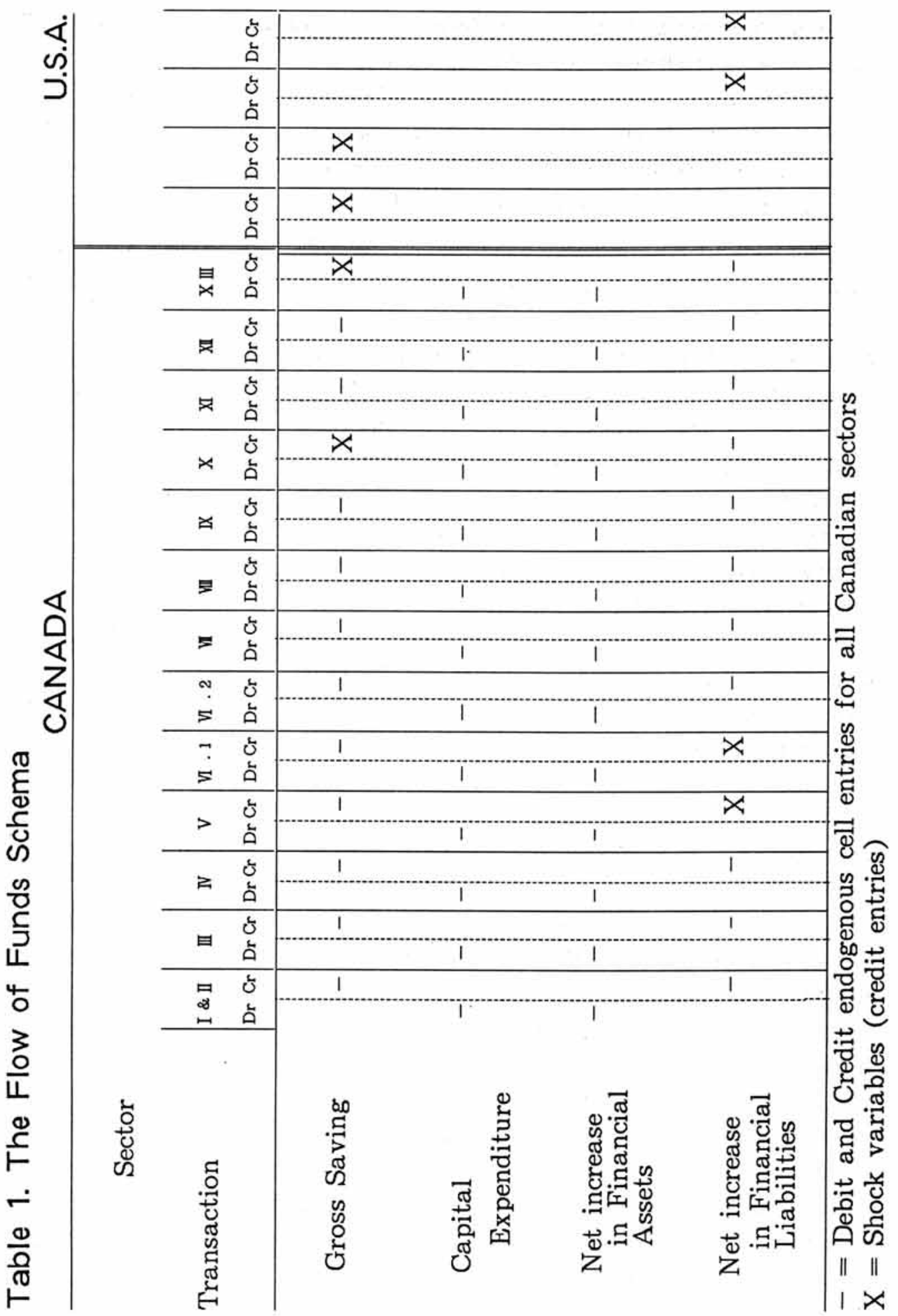


is true for increases in financial assets financed out of borrowing or gross saving. The latter increases result from income increases traceable to the financial shock variable.

The two remaining shock variables appear in the gross saving row of the flowof-funds matrix. Because only credit entries appear in this row, the same-sector source-use linkage described for the financial shock variables is not applicable. Instead, the impact is via gross saving of other sectors (on the same row) or via variables on other rows. Following conventional macrotheory we would expect that the effect on gross saving of other sectors would be deflationary from government surpluses and expansionary from government deficits. The expected sign of the fiscal policy variable is negative: government surpluses are associated with reduced gross saving for other sectors. Similar signs would be anticipated for sector capital expenditures and increases in financial asset due to their being financed by gross saving. On the other hand, the literature on crowding out might suggest a positive relationship between federal gross saving and increases in financial liabilities.

Here government surpluses (used to retire public debt) increase the supply of funds in private capital markets and lead to lower interest rates and greater private borrowings. The negative effects on sector gross saving of an increase in government gross saving is, however, an offsetting influence on the supply of credit. Moreover, if an increase in private sector gross saving due to government deficits encourages sectors to go into debt (complementarity between gross saving and borrowing), the demand for private credit could increase contributing to an increased flow of credit. The increase in government borrowing associated with government deficits therefore need not mean less borrowing by the private sectors of the economy. (For an aggregative treatment of crowding out in terms of both credit and product markets see Cohen 1986, Chap.19) .

Rest of the world saving in the Canadian matrix, when positive, sighifies a Canadian current account dificit. The result should be contractionary on domestic sectors. In this case the sign for the gross saving variables for the non-financial sectors should be negative and similarly for capital expenditures and net increases in financial assets. On the other hand, since the other side of a foreign trade surplus is increased foreign investment, we might expect a positive sign for sector financial liabilities corresponding to the foreign sector's net increase in financial assets.

An alternative theory is not to treat foreign investment as the obverse side of the current account but rather as the dynamic force. The scenario now has capital inflows as the external influence on' the demestic economy. Positive effects then can be rationalized according to this interpretation. 


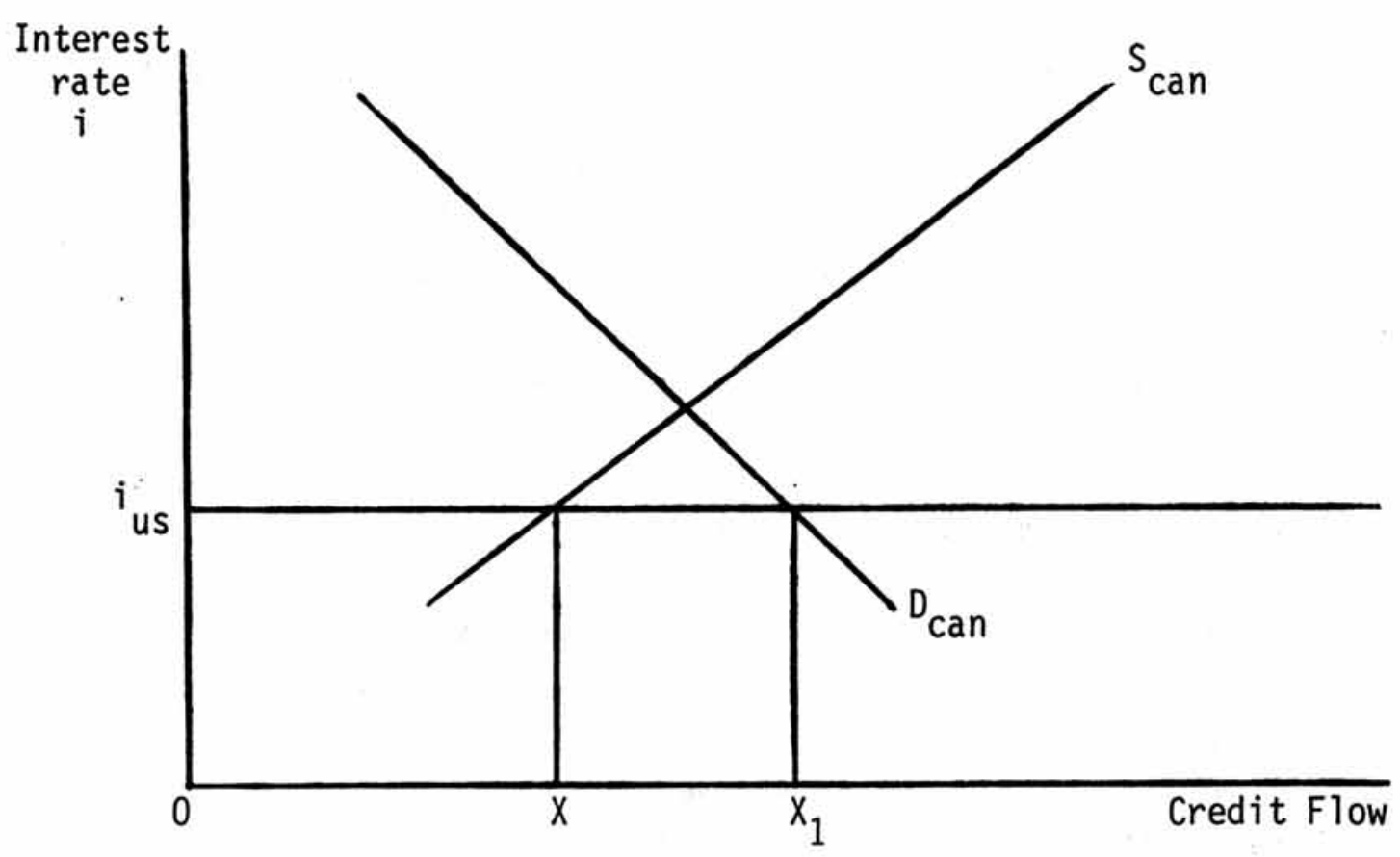

Figure 1.

Interest Rate Changes and Capital Flows

In the case of the U.S. disturbance variables we begin with rest of the world gross saving since the question can be raised if indeed this isn't the only way that the U.S. affects the Canadian economy. If this variable is dominated by the bilateral CanadianU.S. balance of payments we should expect the reverse effects from the Canadian R. O.W. gross saving variable. That is, positive gross saving in the U.S. matrix will stimulate all four flows. Again, the proviso is that the current account dominates balance of payments effects. If capital inflows dominate, negative effects are expected.

Not all efects, however, are siphoned through the balance of payments. There are indirect effects from this variable and also from the three remaining U.S. disturbanses - the federal deficit, Fed policy and commercial bank credit. That is, U. S. monetary and fiscal policies generate interest rate, price effects and exchange rate effects which are translated worldwide through incipient (unrealized) capital flows as implied by international arbitrage. For instance, it has been demonstrated that covered interest parity is maintained between the U.S. and Canada on a daily basis (Husted and Kitchen). This condition guarantees the equality of returns and therefore 
geographic indifference on the part of the marginal ivestor. Given that Canadian and U.S. interest rates move together, an anticipated tightening of U.S. monetary policy could lead to higher interest rates in both the U.S. and Canada and because of interest rate parity this could occur without increases in the volume of international flows of capital. The higher interest rates in Canada could induce sectoral portfolio shifts, asset and liability revaluations and affect real behavior such as sectoral gross saving. A depreciation of the Canadian dollar following monetary tightening in the U.S. will exert output and financial effects. Again, nothing in our testing procedure allows us to identify or distinguish among these effects. The importance of pricetheoretical factors such as these may be enhanced under flexible exchange rates as compared with fixed rates (Central Bank Study group, 1986, Chap.13).

The simultaneous adjustment in domestic and international flows as a result of interest changes associated with U.S. monetary policy may be illustrated by the following simple diagram.

The assumption is that interest rates in U.S. determine Canadian rates. At $i_{\text {us }}$, OX is borrowed by Canadian borrowers in Canada and $\mathrm{XX}_{1}$ amount in the U.S. A tightening, for example, of U.S. monetary policy, will result in the horizontal $\mathrm{i}_{\text {us }}$ line moving up. More funds will be supplied domestically and less will be borrowed internationally. The adjustment of portfolios in response to an interest rate change involve both domestic and international flows.

The expected direct and indirect effects of the shock variables on the endogenous Canadian flow variables can be summarized in the following single equation:

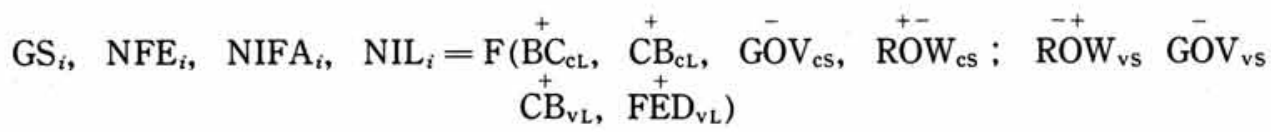
where :

$\mathrm{GS}=$ gross saving

$\mathrm{NFE}=$ capital expenditures

$\mathrm{NIFA}=$ net increase in financial assets

$\mathrm{NIL}=$ net increase in liabilities

$\mathrm{BC}=$ Bank of Canada

$\mathrm{CB}=$ commercial (chartered) banks

$\mathrm{GOV}=$ federal government

ROW $=$ rest of the world

FED $=$ Federal Reserve

and 
the $\mathrm{i}$ subscript $=$ the ith sector

$$
\begin{array}{ll}
\text { c } & =\text { Canada } \\
\text { L } & =\text { increase in liabilities } \\
\mathrm{S} & =\text { gross saving } \\
\mathrm{V} & \quad=\text { United States }
\end{array}
$$

The dual signs above the ROW signify opposing hypotheses about the impact of the rest of the world variable. The work of Bond and Shearer and Lipsey, Sparks and Steiner (cited in Pope, 1981, pp.145-6) emphasize capital flows and would support a positive sign for the R.O.W. in the Canadian matrix and a negative sign in the U.S. matrix. On the other hand, the classic studies of Caves and Reuber covering 1951-70 (1971a, 1971b, and 1973) would make the Canadian current account surplus (with opposite signs) the dynamic factor.

There have been several attempts at linking large scale econometric models of the U.S. and Canadian economies. These efforts include the MPS model of the Federal Reserve Board, the models of Project Link, the RDX2-MPS experiments of the Bank of Canada and the CANDIDE model of the Economic Council of Canada. These models have been used in a variety of simulation exercises to explore questions of policy effectiveness within an open economy and the transmission of policies between economies. The econometric models are linked through trade and aggregate capital flows. None of these models incorporates sectoral balance sheet constraints into its structure. Consequently, these models provide little or no guidance for theorizing at the sectoral level. ${ }^{2}$

\section{Interrelations Among the Discretionary variables}

Discretionary U.S. policies may affect Canadian policy-making. For example, deficit-financing in the U.S. may encourage similar Canadian policies. Or a tighter U.S. monetary policy may lead to a Canadian defense of the exchange rate via monetary policy. For instance, Bordo and Choudhri (1982) find a statistically significant, synchronous relationship between rates of growth in Canadian M1 and U. S. M1. While the comparison of shocks requires their independence (exogeneity), possible relationships among so-called "shock" variables must be confronted.

The data for this study were taken from the Canadian Financial Accounts prepared by Statistics Canada and the U.S. Flow of Funds Accounts compiled by the Federal

${ }^{2}$ For more discussion of these models see Cohen and Husted (1986). 
Reserve. The data are annual observations over the period 1962-1983.

The coefficients in Tables 2 and 3 provide information on the correlations between these variables. To save space in the tables the following codes have been used: rest of the world gross saving ( $45-$ for Canada, V21-for the U.S.), gross saving of the federal government $(\mathrm{C} 45, \mathrm{~V} 28)$, the financial sources of funds of the central bank (C22, V43), and the financial sources of funds of chartered (commercial) banks (C27, V53). In Table 2 we report OLS estimates from regressions of each of the shock variables on the current and lagged varlues of all other shock variables. ${ }^{3}$ Table 3 reproduces the correlation matrices for the subperiods of our data set corresponding to the fixed and floating rate eras of the Canadian dollar. We would have liked to run sets of regressions similar to those in Table 2 for each exchange rate era. Due to an obvious lack of degrees of freedom; however, we chose not to estimate these models.

Some clarification of the concepts of endogeneity and exogeneity is necessary because the same policy may be looked at from two perspectives. For example, Canadian monetary policy may be geared to some exchange rate target. $M_{c a n}=f(E$. R. - E.R.*) where the asterisk signifies the targeted value of the exchange rate. At the same time the exchange rate may be influenced by U.S. interest rates which in turn are a function of U.S. monetary policy. Thus

$$
\text { E. R. }=g\left(r_{u s}\left[M_{u s}\right]\right)
$$

In one sense Canadian monetary policy is exogenous since the response of Canadian policy is to deviations of the exchange rate from a self-declared target value. If, however, Canadian policy is ultimately influenced by U.S. policy, it could be maintained that Canadian policy is endogenous if a relationship between Canadian and U.S. monetary policy can be demonstrated. We shall look at the policy relationships from this perspective.

As the values from both tables suggest, the degree of univariate and multivariate correlation is in general quite strong. The $\overline{\mathrm{R}}^{2}$ from the regressions in Table 2 are very high, exceeding .8 in most cases, and a number of variables are statistically significant. The explanatory power of the monetary policy equations seems somewhat less strong with $\overline{\mathrm{R}}^{2}$ for the U.S. variable falling below.5. In addition, multicollinearity

\footnotetext{
${ }^{3}$ In the table we report the Durbin-Watson statistic to provide a test for the presence of first order serial correlation in the residuals. Given the inclusion of lagged dependent variables in the set of regressors, however, the Durbin-Watson statistic is biased toward rejecting the hypothesis of serial correlation. The lagged dependent variable appears in each equation in order to control for trends in the data. Ideally, we should have fitted transfer function models to each equation. however, the limited number of observations in the data set make this procedure infeasible.
} 


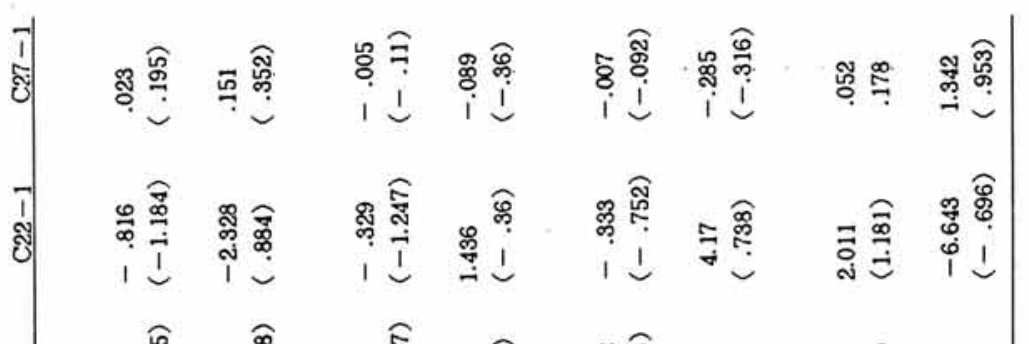

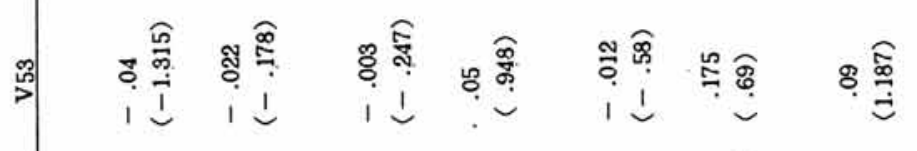

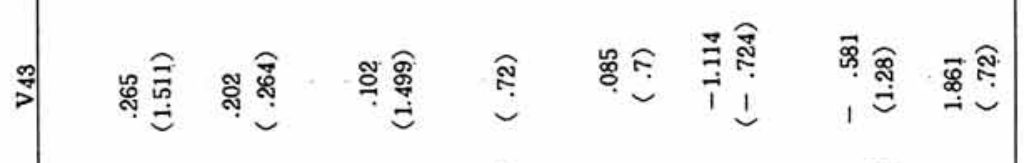

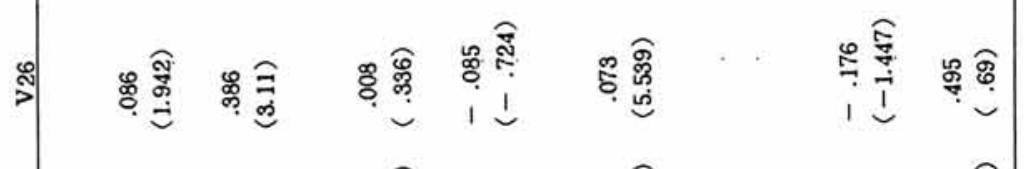

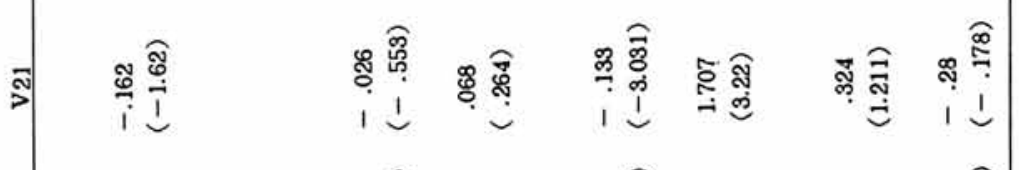

$\frac{\frac{2}{0}}{\frac{0}{2}}$

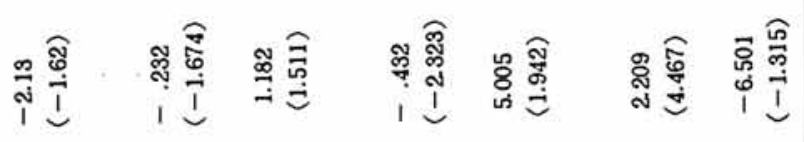

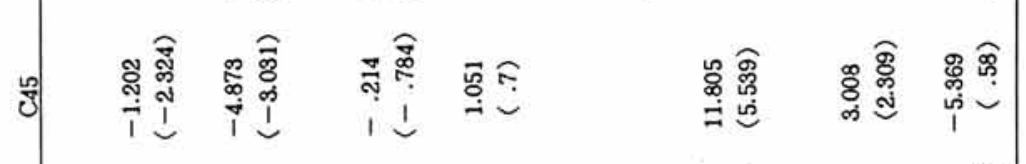

产

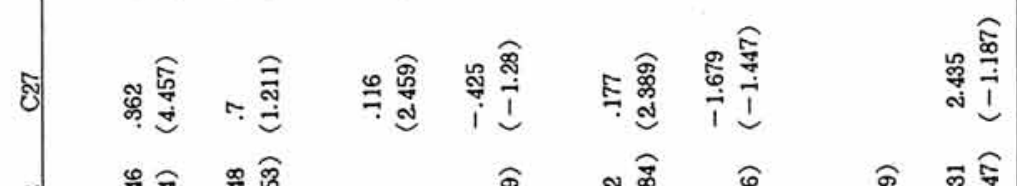

4

告

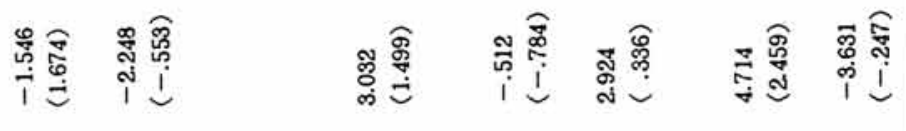

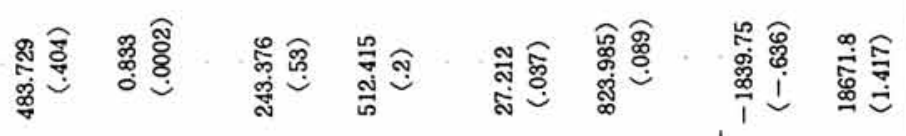

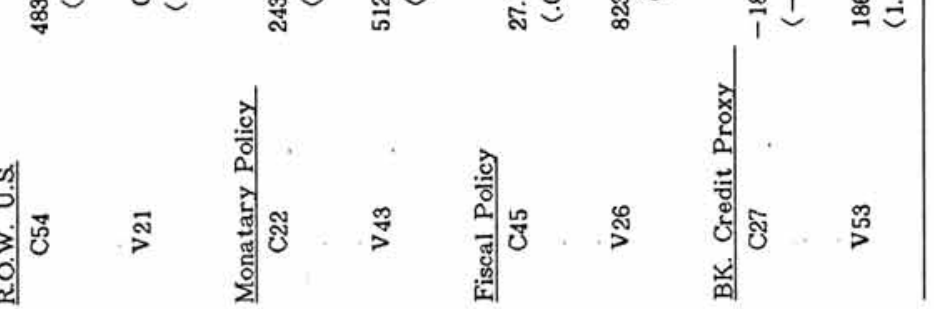




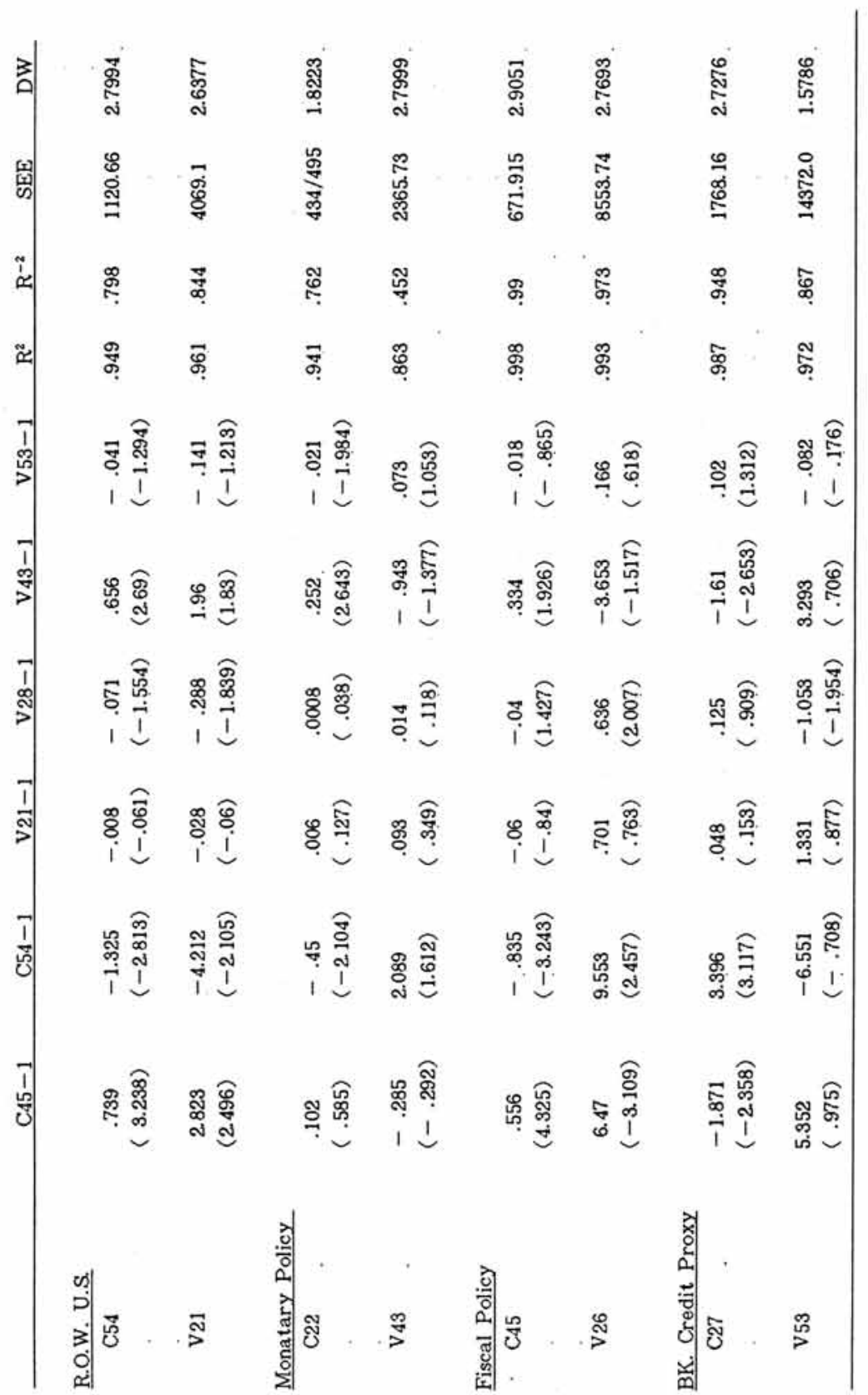


seems to be a problem especially for the U.S. equations-most notably for V21, V43, and V53.

The results in Table 2 do not seem to confirm the results of Bordo and Choudhri and the other researchers described above. That is, contemporaneous levels of U.S. central bank sources of funds (V43) are not significant in explaining Canadian monetary policy. A number of caveats apply, however. First, Bordo and Choudhri compared bilateral movements in another set of variables-the M1s of the two countries and estimated much different model. Second, lagged V43 is positive and significant in the $\mathrm{C} 22$ equations. Third, the high degree of multicollinearity in the data may be obscuring the contemporaneous relationship.

The regressions involving rest of the world gross saving deserve special attention. In a two country world, these variables should be mirror images of each other. Hence if the bilateral balance of payments dominates these sectors, we would expect a negative relationship between the R.O.W. gross savings variables of the two countries. Examining the results we see the negative relationship does emerge in either equation in Table 2 and with both lagged and unlagged data. Only one of these coefficients, however, is significant at the usual confidence intervals. This could be due to the strong multicollinearity in the data. Third country effects (observing the reciprocal relationship) may also be at work.

The disquieting question has to be faced whether the influence of Canada on the U.S. variables may not be as great or greater than the assumed influence of the $\mathrm{U}$. S. on Canada. In terms of the rest of the world gross saving variable, the relations of Table 2 affirm a reciprocal relation. Similarly the relations for fiscal policy suggest a reciprocal influence. A study with similar aims as our own (Burbidge and Harrison 1985) faced the same uncomfortable results with respect to the money supply. Using sophisticated "innovation accounting" techniques, the analysis revealed a "surprisingly strong showing" of the Canadian money supply in its impact on U.S. variables. These variables were the U.S. interest rate and the U.S. money supply (pp.787-8). But obeying their "priors" they suppressed the effect of Canadian variables on U.S. variables by setting to zero the coefficients on all lagged values of Canadian variables in equations explaining U.S. variables. The results (confirmed in an independent test of the impact of U.S. money and Canadian money on U.S. variables) suggested the quantitative unimportance of the Canadian money supply for the U.S. economy.

In contrast to the present interest in flows, Burbidge-Harrison focus on interest rates, the exchange rate, the money stock and indices of prices and industrial production. This chief finding-a not surprising one-is the influence of U.S. interest 
rates on Canadian rates. The study admits to being atheoretical. As discussed earlier, we have attempted to predict on a priori grounds the signs of the Canadian flow-offunds variables.

The primary purpose of Table 3 is to see how relationships between the policy variables were affected by the two exchange rate regimes. The overall results can then be interpreted in terms of the values and implied weights of the two subperiods. The strongest result is support for the greater exogeneity of Canadian monetary policy under flexible rates-a result consistent with the well-known Fleming (1962) and Mundell (1967) studies. We can focus on the C22 and C27 columns which denote credit policy via the Bank of Canada and the chartered banks respectively. The Canadian R. O.W. gross saving variable and the U.S. variables should be singled out for attention. Note the decline in the values in the $\mathrm{C} 22$ and $\mathrm{C} 27$ column under flexible rates. The 890 value in the $\mathrm{C} 22$ column in the fixed exchange rate suggests a strong negative relation between current account deficits ( $\left.\mathrm{C}_{54}\right)$ and central bank credit. The correlation between V21 (U.S. current account deficits) and chartered bank lending under fixed rates is positive. The only significant correlation in these two columns under flexible rates is the positive relation between Canadian R.O.W. gross saving and chartered bank lending. Apart from the greater independence of Canadian monetary variables, the strong relation between the U.S. - Canadian fiscal policy variables for the entire period seems attributable to their relationship during flexible rates.

The evidence prompted us to control for the prevailing exchange rate regime in our analysis of the effects of changes in the exogenous variables on the four categories of flows. Equation 1 (below) was modified to include an interactive dummy variable for the exchange rate regime. The results from this experiment were disappointing. It may be the case that including an interactive dummy variable introduces so much collinearity that precise coefficient estimates cannot be obtained.

\section{Impact of Discretionary Variables}

Here we examine the effects of each of the exogenous variables on the endogenous variables for each of the thirteen sectors of the Canadian economy. In this study we consider only the effects of U.S. and Canadian shock variables on the Canadian sectoral flows. We are implicitly imposing the small country assumption in the case of the Canadian economy. The results of Tables 2 and 3 are resolutely ignored.

A number of theorems exist based on models of an open economy. They describe the expected effects of changes, such as an increase in domestic or foreign money 
Table 3. Correlation Materics for the Descretionary Variables Entire Sample (1962-1983)

$\begin{array}{llllllll}\mathrm{C} 22 & \mathrm{C} 27 & \mathrm{C} 45 & \mathrm{C} 54 & \mathrm{~V} 21 & \mathrm{~V} 28 & \mathrm{~V} 43 & \text { V53 }\end{array}$

\begin{tabular}{|c|c|c|c|c|c|c|c|}
\hline $\mathrm{C} 22$ & 1.000 & & & & & & \\
\hline $\mathrm{C} 27$ & .349 & 1.000 & & & & & \\
\hline $\mathrm{C} 45$ & .059 & .032 & 1.000 & & & & \\
\hline C54 & .201 & $.794 *$ & -.012 & 1.000 & & & \\
\hline V21 & .172 & -.196 & $-.714 *$ & $-.581 *$ & 1.000 & & \\
\hline V28 & .023 & .141 & $.920 *$ & .044 & $-.535 *$ & 1.000 & \\
\hline V43 & -.006 & .362 & $-.572 *$ & $.469 *$ & .235 & $-.535 *$ & 1.000 \\
\hline V53 & .207 & $.459 *$ & $-.775 *$ & .340 & $.630 *$ & $-.581 *$ & $.673 *$ \\
\hline
\end{tabular}

Fixed Exchange Rate Era (1962-1970)

$\begin{array}{llllllll}\mathrm{C} 22 & \mathrm{C} 27 & \mathrm{C} 45 & \mathrm{C} 54 & \mathrm{~V} 21 & \mathrm{~V} 28 & \mathrm{~V} 43 & \text { V53 }\end{array}$

C22 1.000

C17 $\quad .545 \quad 1.000$

$\begin{array}{llll}\mathrm{C} 45 & .050 \quad .439 & 1.000\end{array}$

C54 - 5 .890* $\quad-.482 \quad .264 \quad 1.000$

V21 $.091 \quad .789 * \quad .360 \quad-.095 \quad 1.000$

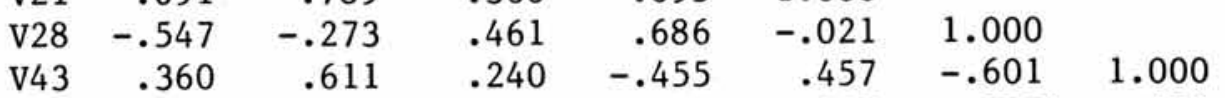

$\begin{array}{lllllllll}\mathrm{V} 53 & .527 & .548 & -.192 & .547 & .307 & -.793 * & .453 & 1.000\end{array}$

Flexible Rate Era (1971-1983)

\begin{tabular}{|c|c|c|c|c|c|c|c|c|}
\hline C22 & $\begin{array}{l}\mathrm{C} 22 \\
1.000\end{array}$ & $\mathrm{C} 27$ & C45 & C54 & V21 & V28 & V43 & V53 \\
\hline $\mathrm{C} 27$ & .318 & 1.000 & & & & & & \\
\hline$C 45$ & .196 & .335 & 1.000 & & & & & \\
\hline C54 & .234 & $.768 *$ & .257 & 1.000 & & & & \\
\hline V21 & .135 & -.391 & $-.698 *$ & -.315 & 1.000 & & & \\
\hline V28 & .191 & .518 & $.894 *$ & .353 & -.535 & 1.000 & & \\
\hline V43 & -.302 & .042 & -.364 & .307 & .017 & -.231 & 1.000 & \\
\hline V53 & .062 & .197 & $-.719 *$ & .051 & $.686 *$ & -.421 & .225 & 1.000 \\
\hline
\end{tabular}

(*) indicates that the correlations are significantly different from zero at the 5\% leve1. 
Journal of International Economic Integration

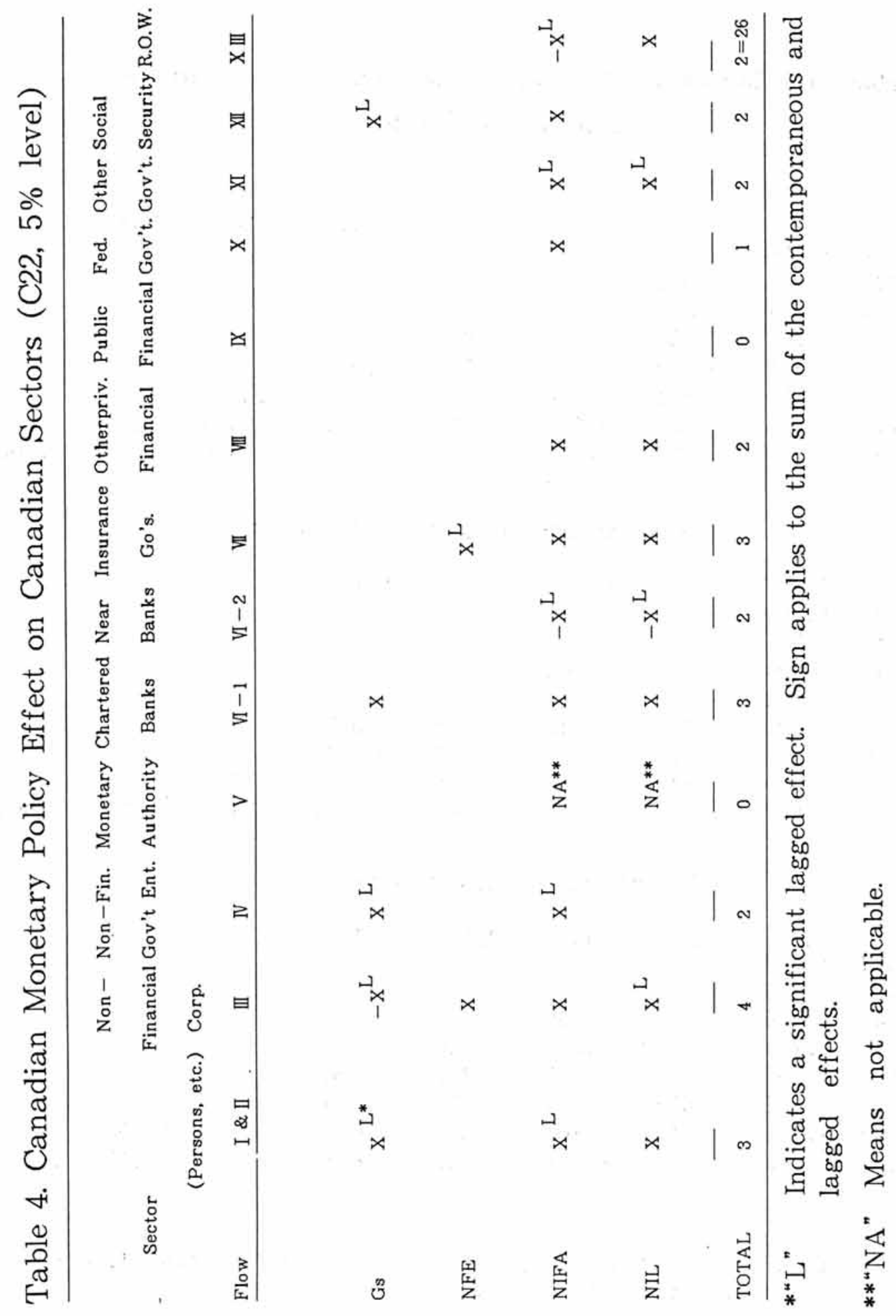


J.Cohen and S. Husted

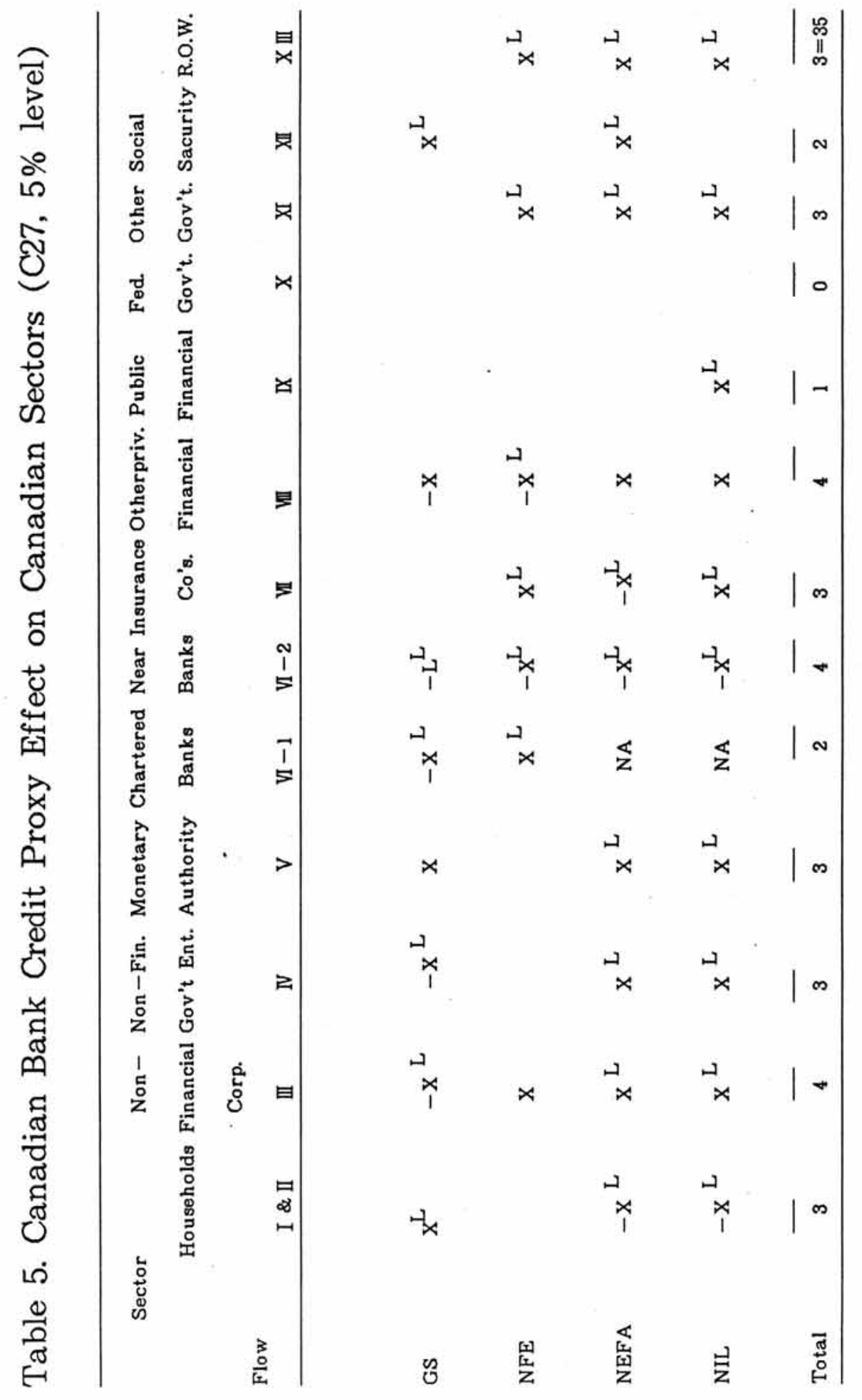




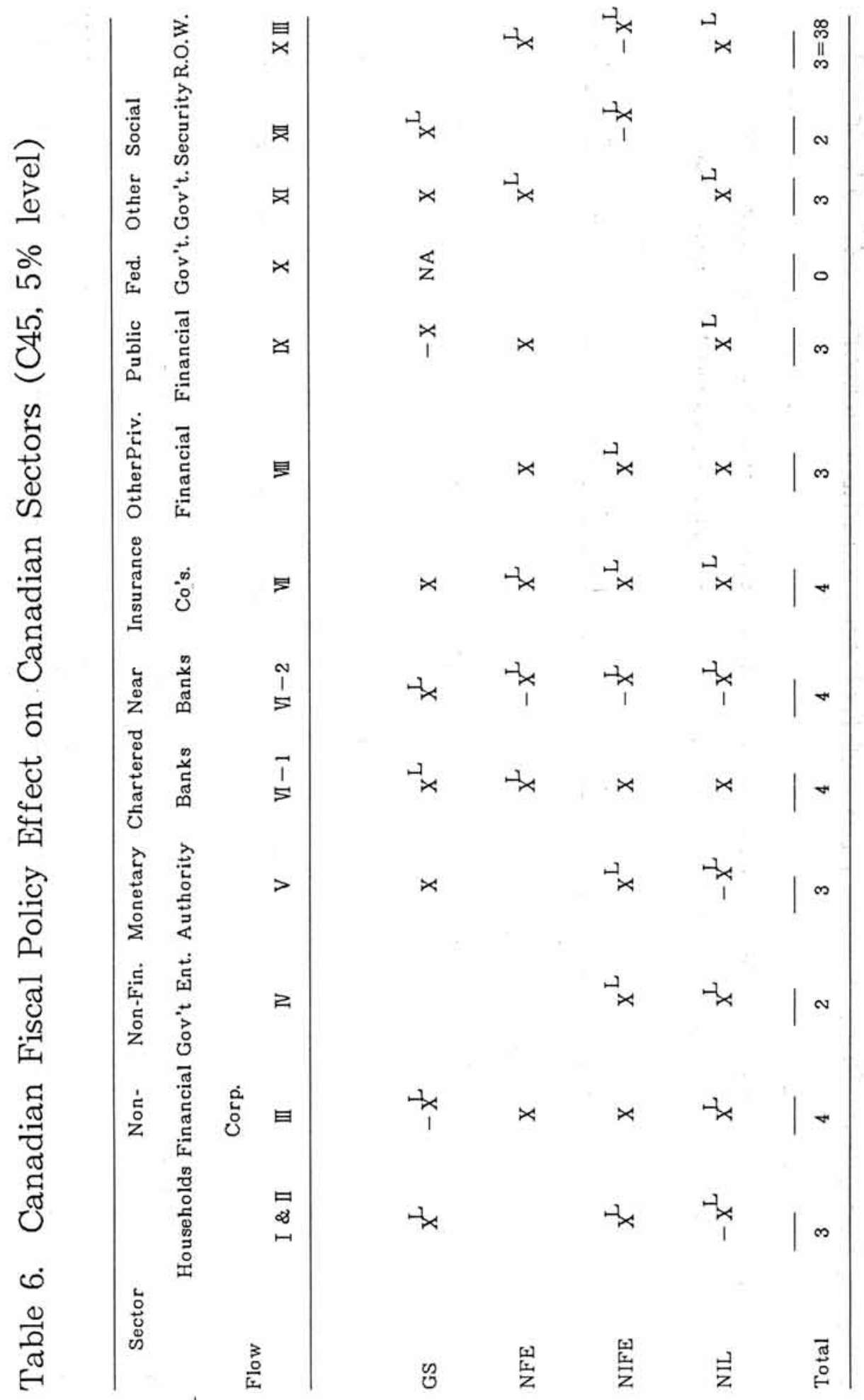




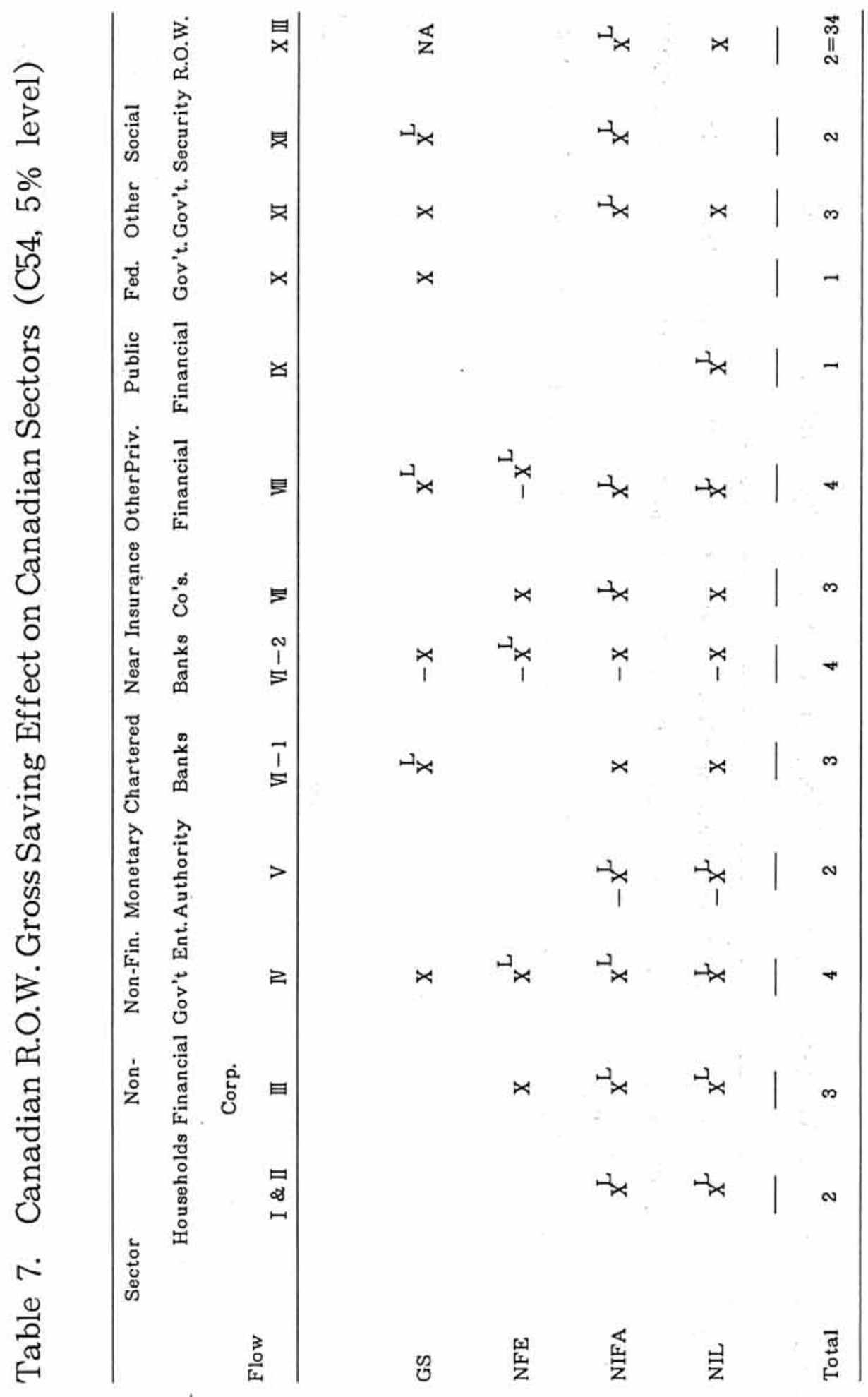




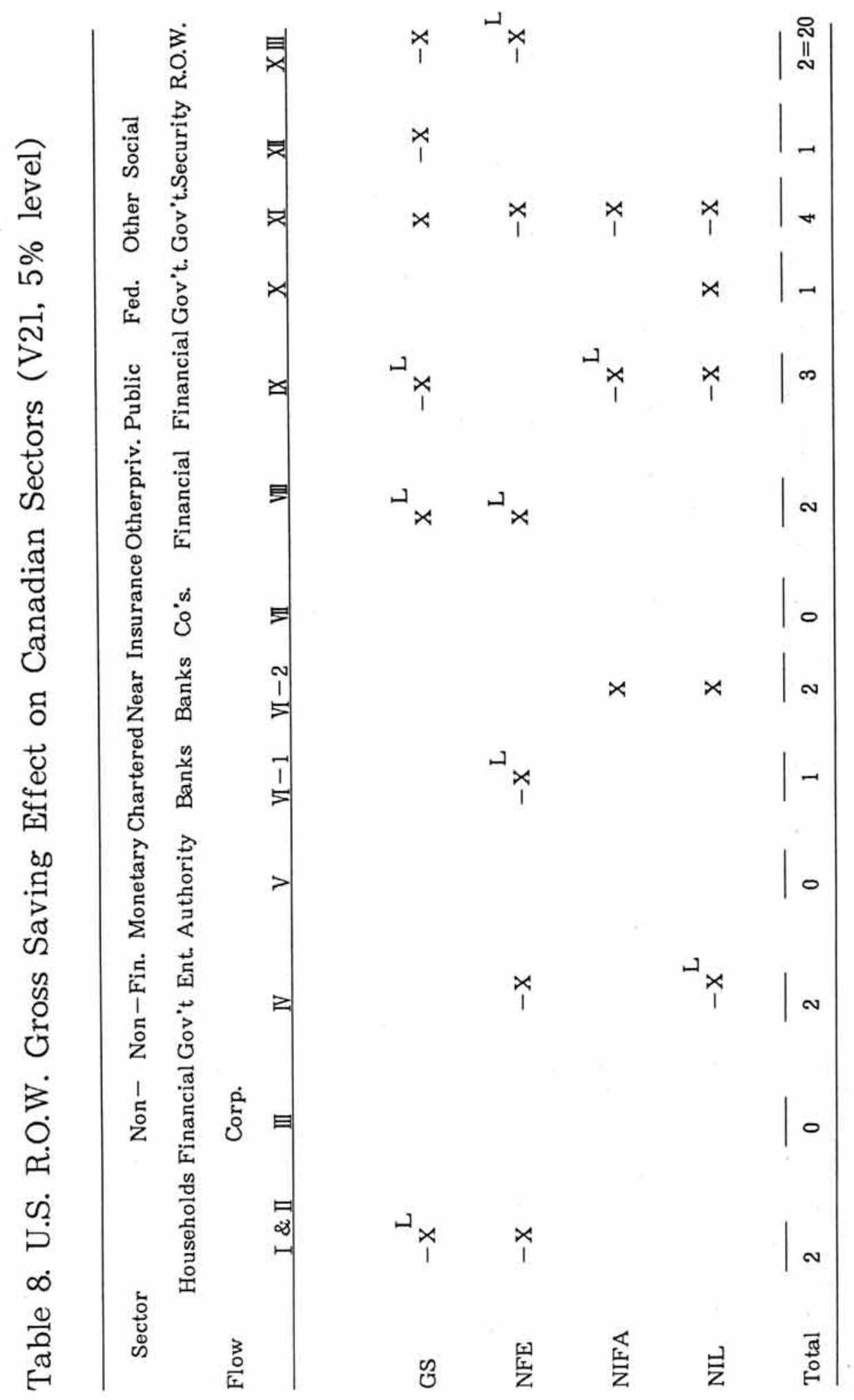


J.Cohen and S. Husted

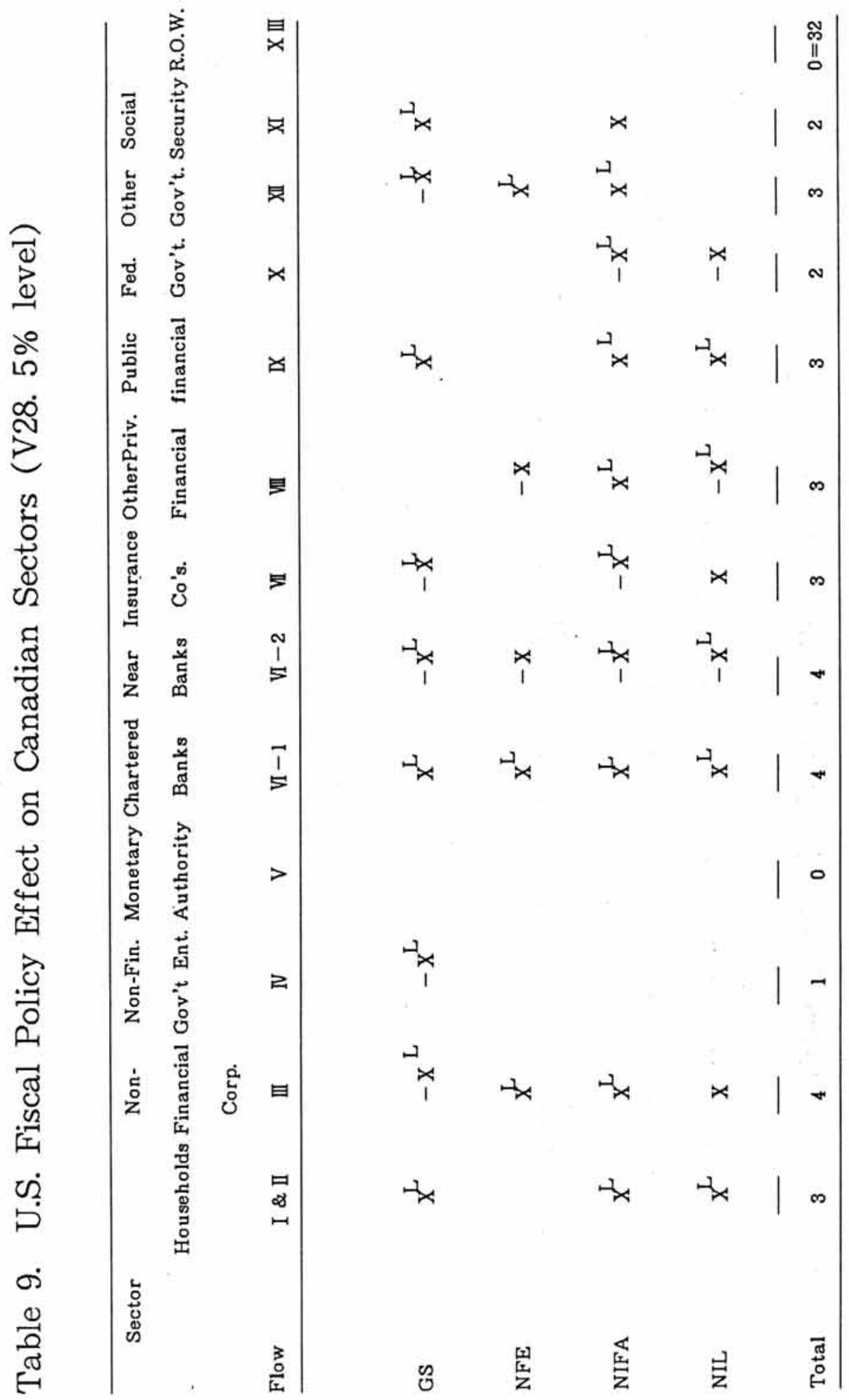




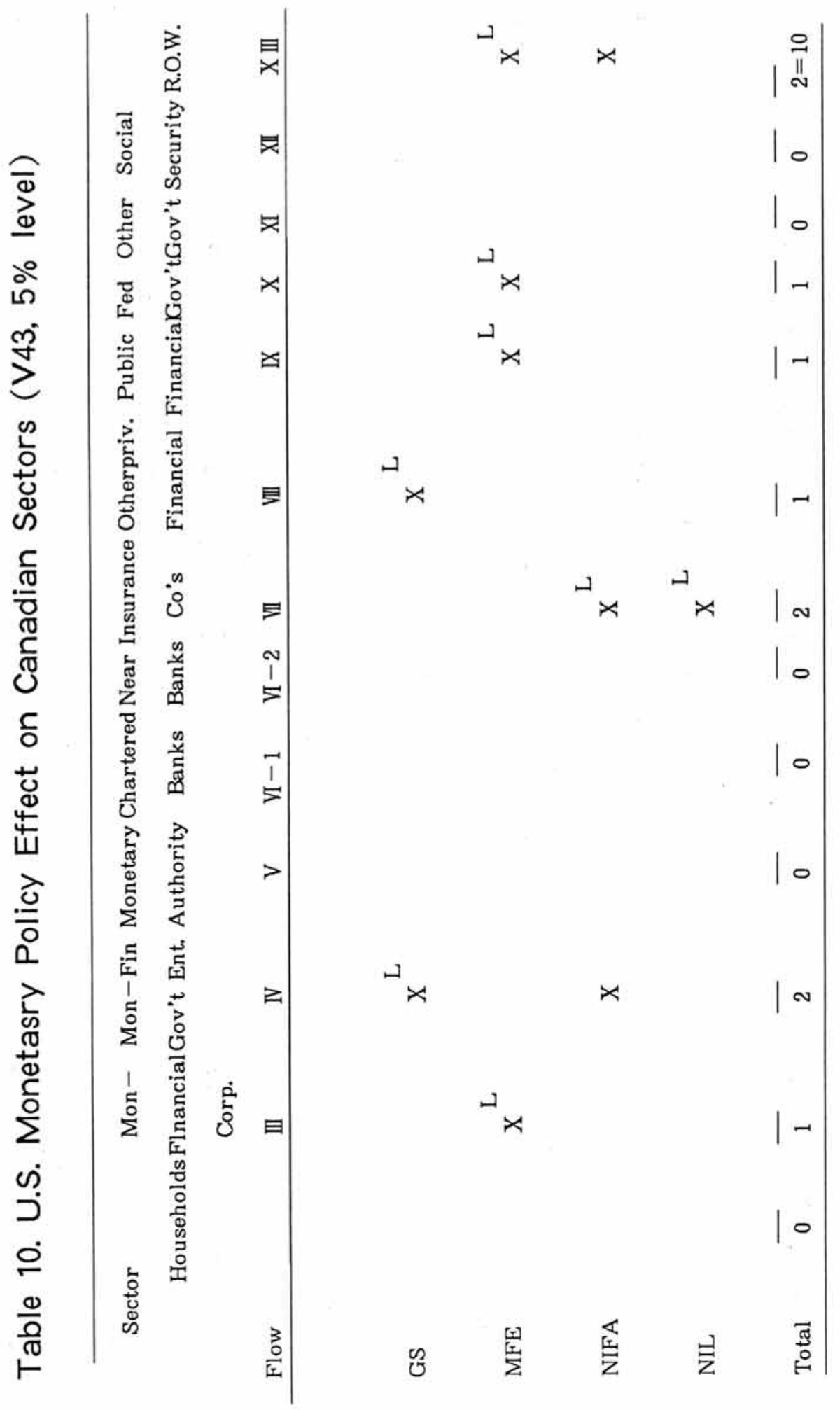




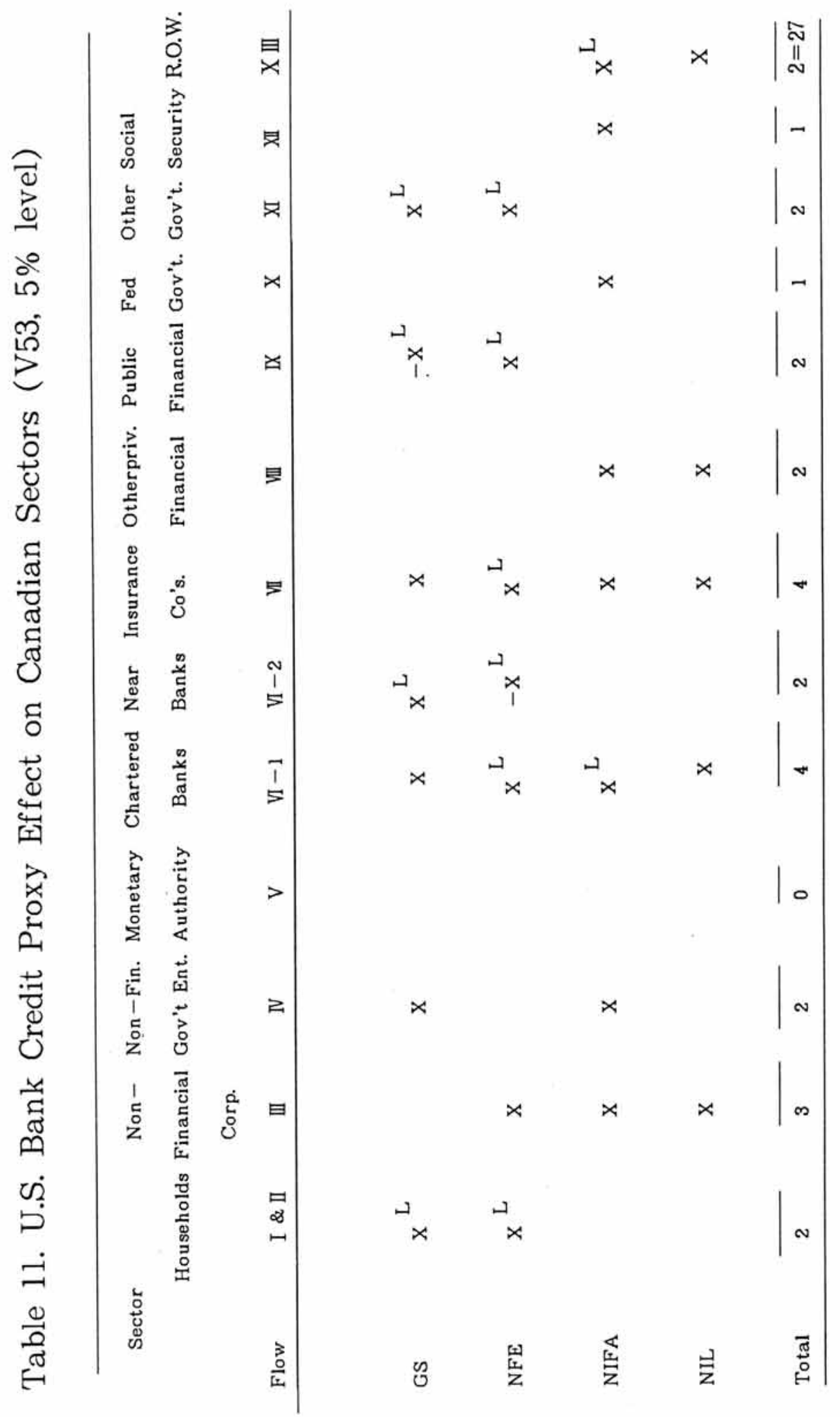




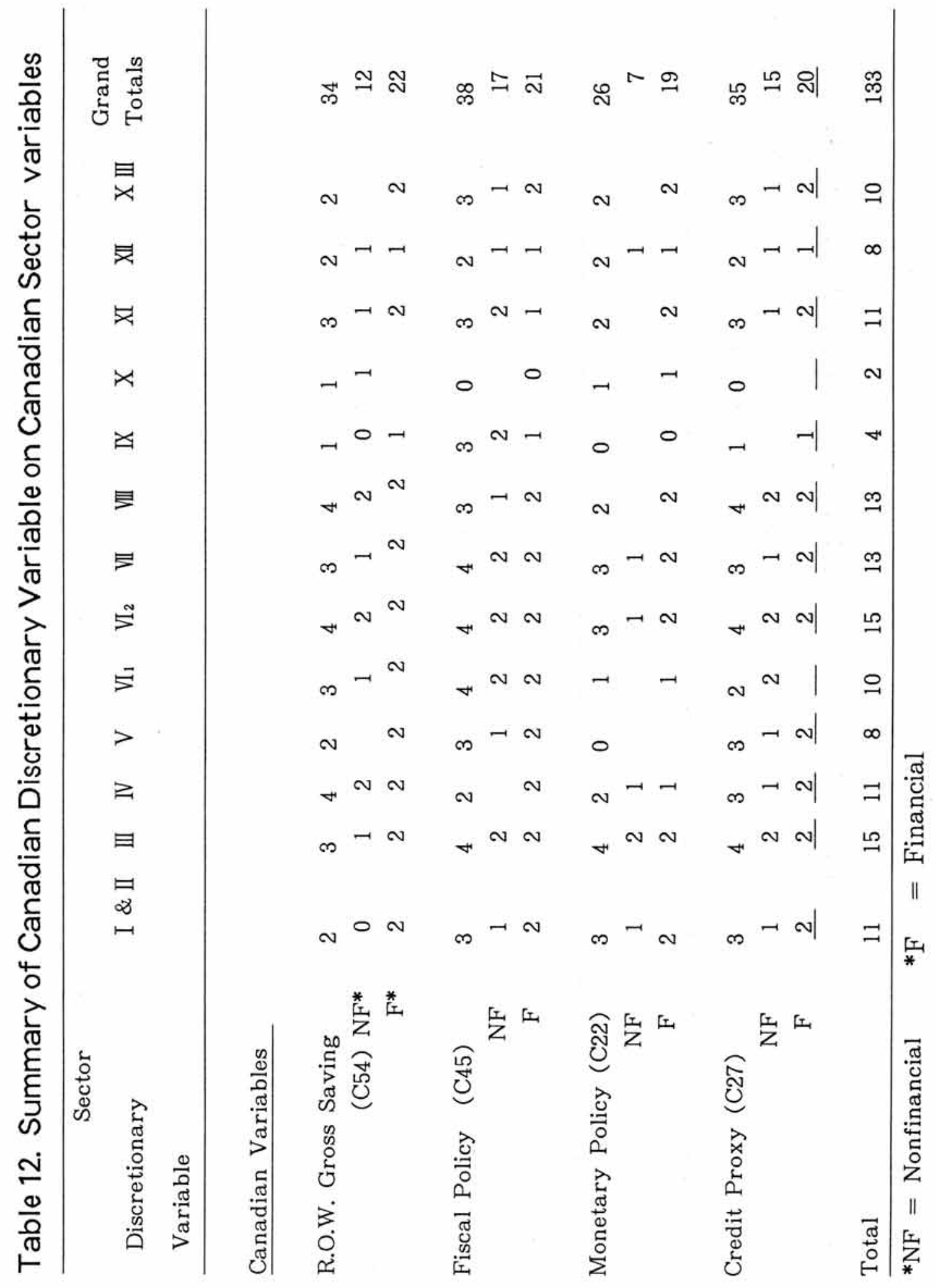




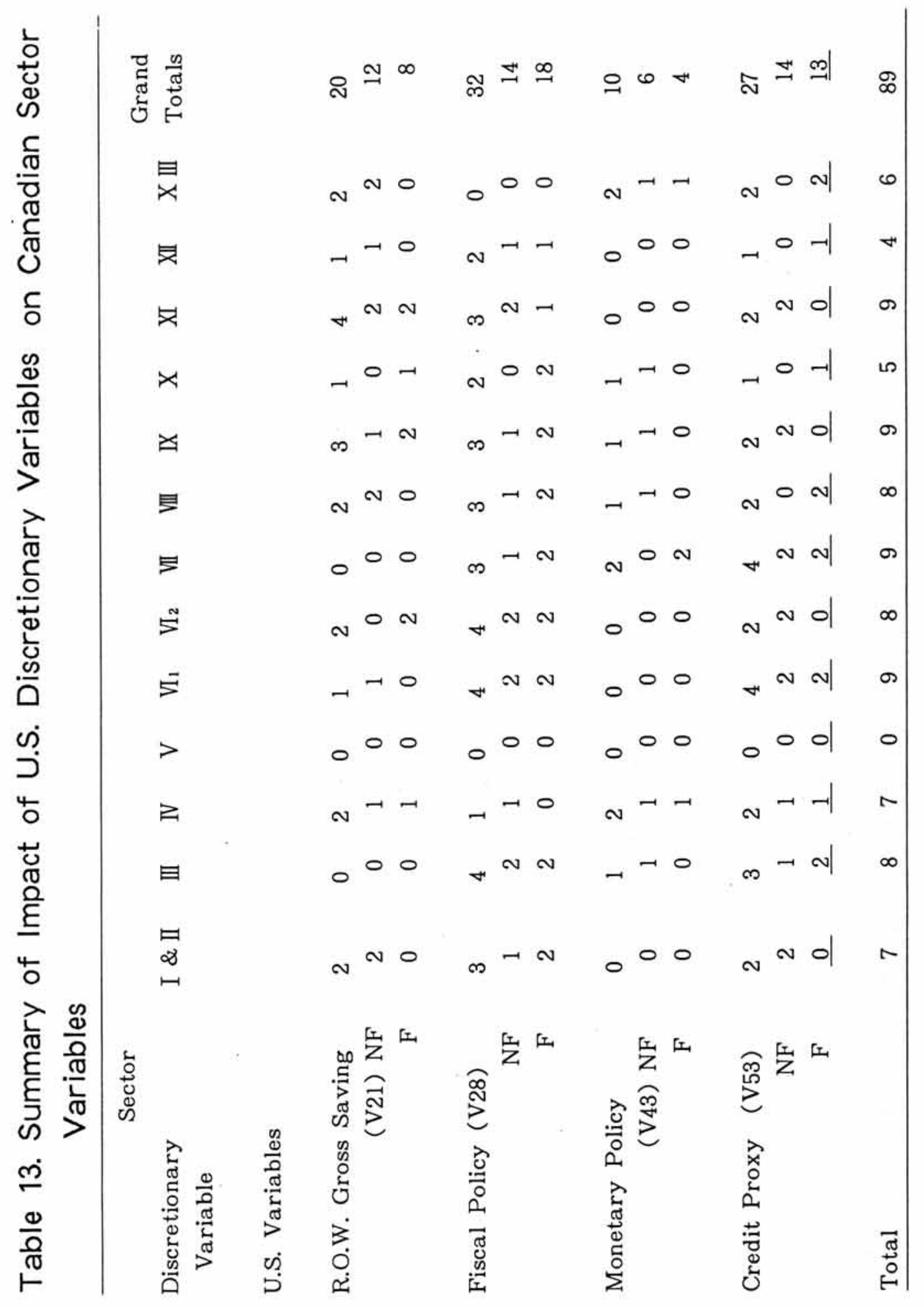


supply, on the aggregate behavior of an economy. Less well established however is how these changes affect an economy at the sectoral level. Our empirical work represents an effort towards understanding these effects in a flow of funds framework.

Tables 4 through 11 give a complete description of our results. Tables 12 and 13 summarize these results. In constructing these tables, the following strategy was employed. We estimated models of the form :

$\mathrm{Y}_{\mathrm{t}}^{i j}=\alpha+\beta_{1} \mathrm{Y}_{\mathrm{t}-1}^{i j}+\beta_{2} \mathrm{Y}_{\mathrm{t}-2}^{i j}+\gamma_{1} \mathrm{X}_{\mathrm{t}}^{\mathrm{k}}+\gamma_{2} \mathrm{X}_{\mathrm{t}-1}^{\mathrm{k}}+$ disturbance

where:

$\mathrm{Y}_{\mathrm{t}}^{i j}=$ the $\mathrm{jth}$ sectoral flow of sector $\mathrm{i}$ at time $\mathrm{t} ; \mathrm{j}=$ gross savings, nonfinancial investment, increase in financial assets, increases in liabilities : $\mathrm{i}=\mathrm{I}-\mathrm{X}$ III

$\mathrm{X}_{\mathrm{t}}^{\mathrm{k}}=$ the level of $\mathrm{kth}$ exogenous flow at time $\mathrm{t} ; \mathrm{k}=$ Canadian or U.S. credit policy, monetary policy, fiscal policy or R.O.W. gross saving.

$\alpha, \beta_{i}, \gamma_{i}=$ coefficients to be estimated.

In addition to estimating equation (1) for each sectoral flow and exogenous shock, we experimented with three restricted forms of the general model. These were generated by setting alternately $\beta_{2}, \gamma_{2}$ and $\beta_{2}$ and $\gamma_{2}$ equal to zero. From these four equations, the model which produced the lowest standard error of regression was chosen. In the tables we have inserted $\mathrm{Xs}$ to denote those sectors where significant effects (at the $5 \%$ level) from the exogenous variables were found. If the effect was negative we have inserted a minus (-) sign. If there was a significant lagged effect, we have added a superscript $\mathrm{L}$ and the sign on the $\mathrm{X}$ represents the sign of the sum of the contemporaneous and lagged coefficients of the exogenous variable.

Ideally, in estimating each of these equations we should have taken into account the adding up constraints implied by the flow of funds matrix. This would have produced more efficient estimates. We did not do this for several reasons. First, the computational burden implied in estimating the constrained system is enormous. Second, while our estimates are inefficient they are unbiased so long as standard assumptions apply. Taking into account the flow constraints will not change this property. Finally, our principal concern in this section is with signs rather than magnitudes so that an inefficient estimation technique does not appear to be a problem. We do note, however, that due to the use of an inefficient estimation technique the number of significant effects we report is probably a lower bound of the number that would be found if the constrained system of equations was estimated. 
A detailed analysis of the tables offers these general conclusions :

1. Changes in U.S. values are less likely to have significant impacts on sectoral behavior in Canada than changes in analogous Canadian variables. The Canadian monetary policy variable (C22) was significant in 26 cases: Canadian bank credit (C27) in 35 cases; Canadian government gross saving (C45) in 38 cases and the Canadian R.O.W. gross saving in 34 cases. The total number of significant effects was 133 out of a possible 208 cases. The comparable values for U.S. variables were 10 , 27,32 , and 20 , for a total of 89 .

2. Canages in any exogenous variable, regardless of country, lead to similar behavior across all sectors. Changes in Canadian exogenous variables had coefficients with the same sign $78 \%$ of the time. U.S. magnitudes had coefficients which agreed in sign $81 \%$ of the time.

3. Except for changes in the current accounts (R.O.W. gross savings) movements in Canadian and analogous U.S. variables produce qualitatively similar patterns in the directions of movement of the endogenous variables.

For instance, an increase in the Canadian (U.S.) monetary base leads to sectoral increases in gross saving in $80 \%(100 \%)$ of the significant cases; increases in nonfinancial investment in $100 \%(100 \%)$ of the significant cases and a net increase in liabilities in $88 \%(100 \%)$ of the significant cases. Overall, the percentages of positive signs are $84 \%(100 \%)$. A lesser degree of overall correlation in significant positive signs exist between Canadian and U.S. bank credit equations (91\% and $66 \%$ ) and between Canada and U.S. government gross saving equations, ( $74 \%$ and $58 \%$ ).

A more demanding test is to compare signs by individual cells. For monetary policy five out of six of the eligible cells agree in sign (83\%) ; for bank credit $79 \%$ ( 15 out of 19 ) : for fiscal policy $71 \%$ (20 out of 28 ). The majority of the significant signs are positive which is consistent with our earlier theorizing. Most negative effects appear with the fiscal policy variable. Rather than the deflationary impact associated with crowding out, negative signs suggest that increases in the government deficit (negative gross saving) have a positive effect on the economy.

4. The mirror-image effect expected of the R.O.W. gross saving variables is verified and the signs support net foreign investment as the transmission mechanism.

An increase in Canadian R.O.W. gross saving, equivalent to an increase in the Canadian current account deficit should have depressing effect on the Canadian economy since the trade balance is deteriorating. And yet we find mostly positive effects. The explanation lies in the alternative hypothesis that the impetus of the foreign sector is via net foreign investment (portfolio and direct) rather than via the 
trade surplus. The lagged significant effects in Tables 7 and 8 strengthen the case for exogeneity. While the identity of capital flows and the current account are recognized, the positive signs suggest that the dynamics lie with capital flows.

As previously mentioned, our results are in keeping with the views of several Canadian authorities cited in W. H. Pope (1981, pp.145-6). On the other hand, they may be at variance with the classic studies of Richard E.Caves and Grant L. Reuber covering 1951-52 (1971a, 1971b, 1973). For them, the lead-lag patterns demonstrated that changes in the balance of trade preceded changes in long-term capital flows. Because of their disaggregation of the balance of payments, they could escape the identity of the current account and total capital flows implicit in our analysis. They emphasize that their results are not consistent with the view that capital flows are the predominant source of disturbances in Canada's balance of Payments (1971, p.12).

5. Changes in U.S. variables are more likely to affect nonfinancial variables in Canada. Changes in Canadian variables are more likely to affect portfolio (financial) variabels. Of the 133 significant coefficients on Canadian exogenous variables only 51 (or $38 \%$ ) involved nonfinancial (gross saving or nonfinancial investment) variables. One third of these were from the Canadian fiscal policy equations. On the other hand 46 (or $52 \%$ ) of the 89 significant coefficients for U.S. exogenous variabels have their impact on Canadian nonfinancial flows. These are from equations involving three different exogenous shocks: U.S.R.O.W. gross saving, U.S. government gross saving and U.S. credit policy.

The sharp contrast between financial and nonfinancial effects is slightly weakened if we concentrate on the major spending sectors. In particular, no real U.S. impact is registered for the business sector (III). Nevertheless, we take it to be important evidence of U.S. influence that the U.S. exerts more real effects than Canada (in absolute numbers) and overwhelmingly so in relative terms (relative to each country's financial effects).

\section{The Sector by Sector Picture}

The analysis has summed up the effects of individual shock variables on the various Canadian sectors. If we focus on sector by sector analysis, substantial differences in Canadian-U.S. impacts are revealed. In one case-Public Financial Institutions-the total U.S. impact (as measured by the number of significant effects) exceeds the Canadian. At the other extreme are the private sectors ( I \& II, III), the Bank of Canada (V) and XII (Social Security Funds) which are primarily influenced by 
Canadian shocks.

What is also noteworthy is the apparent substitutionary relationship between chartered banks and near banks in response to domestic Canadian shocks and U.S. fiscal policy. (Tables 4, 5, 6, and 9). Chartered bank expansion is at the expense of near banks. At the same time since we did not block out the coefficient of shock variables as "not applicable" when they appeared in tables featuring other shock variables, we can perceive the strong positive correlation between central bank and chartered bank behavior.

\section{The Big and Small Picture}

What do we conclude about Canadian economic independence? In terms of polarities and answer is easy. Neither extremes of independence and dependence are tenable. There are too many U.S. effects on the endogenous Canadian variables to speak of Canadian economic independence and there are too many Canadian shock effects to speak of Canadian dependency. In studying the relationship between the two sets of shocks variables the implication is one of independence of Canadian monetary policy. The results of fiscal policy demonstrate parallelism in policy-making in the two countries. The relationship between the gross saving variables is consistent with the study of the effects of the respective shock variables on the Canadian variables. The well-known linkage of the two countries via the balance of payments is confirmed. Perhaps our most valuable finding is that it is not the current account surplus that sparks the Canadian economy but rather net capital inflows.

\section{FUTURE WORK}

Every economy has many economic sectors with distinctive decision-making characteristics. This is the rationale for modeling Canadian-U.S. linkages in a flow of funds accounting framework. The shortcomings of autoregressive methods make more demanding estimation and forecasting techniques inevitable. Considerable econometic modeling has been done for U.S. - Canadian economic relations and advantage should be taken of this work. (See Cohen-Husted, 1986, pp.89ff for a review of these studies.) At the same time, some tedious fact-grubbing has to be done to reconcile the bilateral balance of payments so that the model can work with two subsectors of the rest of the world for each country. Until then, the better documented Canadian version of the bilateral balance of payments has to be imposed on the U.S. matrix.

The challenge is to carry on such model-building subject to the full constraints of 
the accounts. That this is a difficult task is well demonstrated by the paucity of such studies. (Perhaps Patric H. Hendershott, 1977, is the only detailed modeling that is consistently faithful to the flow-of-funds constraints.) The point of emphasis of such model-building might be to test the role of capital flows in the Canadian economy and their interrelationship with monetary and fiscal policy. Unlike the Caves-Reuber studies which in effect are based on a two-sector model of the economy, the tracking of capital flows effects would take place in a multi-sector context with full detail on both real and financial flows.

\section{References}

Brodo, M. and E. Choudhri, "The Link Between Money and Prices in an Open Economy : Canadian Evidence from 1971 to 1980, " Federal Reserve Bank of St. Louis, Review 64 (August/September 1982), 13-23.

Burbidge, John and Alan Harrison, "(Innovation) Accounting for the Impact of Fluctuations in U.S. Variables on the Canadian Economy, " Canadian Journal of Economics, XVIII (November, 1985), 784-798.

Caves, Richard E. and Grant L. Reuber, Capital Transfers and Economic Policy (Cambridge, Mass., 1971a).

, "International Capital Markets and Economic Policy Under Flexible and Fixed Exchange Rates, 1951-70, " in Federal Reserve Bank of Boston, Canadian-

United States Financial Relationships, Conference Series, No.6 (September, 1971 b), $9-40$.

, "Canadian Economic Policy and the Impact of International Capital Flows" in Private Planning Association of Canada, Capital Flows and International Policy Harmonization (Toronto, Ont., 1973), 1-82.

Jacob Cohen, Money and Finance: A Flow-of-Funds Approach (Ames, Iowa, 1986).

and Steven Husted, "An Integrated Accounting matrix for Canada and the United States, "American economic review, 75 (May, 1985), 211-216.

"Modeling Canadian-U.S. Linkages in a Flow-of-Funds Framework," (Pittsburgh, Pa., April 1986), unpublished paper.

Hendershott, Patric H., A Flow-of-Funds Financial Model (Lexington, mass., 1977).

Husted, Steven and John Kitchen, "Some Evidence on the International Transmission of U.S. Money Supply Announcement Effects," Journal of money, Credit and 
Banking, 17 (November, 1985), 456-66.

Pope, W. H., "International Economic Relations," in R. C. Bellan and W. H. Pope, co-eds., The Canadian economy : Problems and Options (Toronto, Ont., 1981), chap. 8 .

Study Group of the Group of Ten Countries, Recent Innovations in International Banking (Bank for International Settlements, Basle, Switzerland, 1986). 